\title{
MEWUJUDKAN INTEGRASI DATA MELALUI IMPLEMENTASI INOVASI PELAYANAN KESEHATAN BERBASIS TEKNOLOGI DIGITAL
}

\author{
Deby Febriyan Eprilianto \\ Jurusan Administrasi Publik, Fakultas Ilmu Sosial dan Hukum, Universitas Negeri Surabaya \\ debyeprilianto@unesa.ac.id \\ Yuyun Eka Kartika Sari \\ Magister Administrasi Publik, Fakultas Ilmu Sosial dan Politik, Universitas Gadjah Mada \\ kartikasariyuyuneka@gmail.com

\section{Boni Saputra} \\ Jurusan Ilmu Administrasi Negara, Fakultas Ilmu Sosial, Universitas Negeri Padang \\ bonisaputra@fis.unp.ac.id
}

\begin{abstract}
Abstrak
Inovasi saat ini lebih cenderung dilakukan oleh sektor swasta dalam memberikan pelayanan kepada pelanggannya. Keberhasilan sektor swasta dengan berbagai inovasinya memberikan suntikan motivasi bagi sektor publik dalam melakukan pengembangan inovasi untuk memberikan pelayanan kepada masyarakat. Tetapi yang terjadi di Indonesia, inovasi masih identik dengan pemanfaatan Teknologi Informasi dan Komunikasi (TIK) dalam aktivitas proses administrasi publik. Oleh karena itu terdapat berbagai bentuk inovasi dalam sektor publik berbasis TIK yang telah dilakukan diberbagai sektor antara lain e-education, e-health, e-tourism, e-budgeting, e-procurement, dan lain sebagainya. Di era digital saat ini memberikan peluang besar kepada sektor publik untuk dapat mengembangkan berbagai inovasi dengan memanfaatkan TIK, sehingga dapat meningkatkan kualitas pelayanan publik kepada masyarakat. Tujuan dalam penelitian ini adalah untuk mengetahui dan mendeskripsikan proses pengembangan dan implementasi inovasi aplikasi SIMPUS untuk mewujudkan integrasi data kesehatan di Kota Yogyakarta. Penelitian ini dilakukan pada Pemerintah Kota Yogyakarta dengan unit analisis Dinas Kesehatan dan Puskesmas di Kota Yogyakarta. Metode yang digunakan dalam penelitian ini adalah deskriptif kualitatif melalui wawancara, observasi, dan dokumentasi. Hasil penelitian ini menunjukkan bahwa bentuk inovasi aplikasi SIMPUS yaitu inovasi proses administrasi berbasis teknologi yang dibuat oleh Dinas Kesehatan Kota Yogyakarta pada tahun 2012 untuk diterapkan di seluruh Puskesmas. Setidanya terdapat 18 Puskesmas Utama dan 12 Puskesmas Pembantu, sehingga keseluruhan jumlah puskesmas yang ada di Kota Yogyakarta sebanyak 30 puskesmas yang menerapkan aplikasi SIMPUS. Stakeholder yang terlibat dalam pengembangan dan implementasi SIMPUS di Kota Yogyakarta antara lain : a) bagian Teknologi Informasi dan Telematika (TIT), Dinas Kesehatan dan seluruh Puskesmas di Kota Yogyakarta. Stakeholder yang paling berperan dalam implementasi SIMPUS yaitu Dinas Kesehatan dan puskesmas. Manfaat yang dirasakan dalam implementasi SIMPUS yaitu terwujudnya integrasi data kesehatan. Dimana Dinas Kesehatan dapat mengakses dan memanfaatkan data kesehatan yang ada di SIMPUS kapanpun dan dimanapun dengan mudah pada setiap puskesmas.
\end{abstract}

Kata Kunci: Sistem Informasi Manajemen, Pelayanan Kesehatan, dan Integrasi Data

\begin{abstract}
Innovation is now more than done by the private sector in providing services to its customers. The success of the private sector with various innovations provides an injection of motivation for the public sector in developing innovations to provide services to the community. However, what happens in Indonesia is still related to the use of Information and Communication Technology (ICT) in public administration process activities. By ICT which has been carried out in various sectors including e-education, e-health, e-tourism, ebudgeting, e-procurement, and so forth. In the current digital era, it provides a great opportunity for the public sector to be able to develop various innovations by utilizing ICT, so as to improve the quality of community services for the community. The purpose of this research is to study and describe the process of developing and implementing the SIMPUS application to realize the integration of health data in the city of Yogyakarta. This research was conducted at the Yogyakarta City Government with an analysis unit of the Health Service and Puskesmas in the City of Yogyakarta. The method used in this research is descriptive qualitative through interviews, observations, and documentation. SIMPUS is a technology-based administrative process innovation created by the Yogyakarta City Health Office in 2012 to be implemented
\end{abstract}


in all Puskesmas. At the same time there are 18 Primary Health Centers and 12 Supporting Health Centers, so that the total number of Puskesmas in the City of Yogyakarta is 30 Health Centers that require the SIMPUS application. Stakeholders involved in the development and implementation of SIMPUS in the City of Yogyakarta include: a) the Information Technology and Telematics (TIT) section, the Health Service and all Puskesmas in the City of Yogyakarta. The most important stakeholders in the implementation of SIMPUS are the Health Office and Puskesmas. The benefits understood in the implementation of SIMPUS are the realization of integration of health data. Where the Health Department can be accessed and use the health data that is in SIMPUS anytime and anywhere easily in each puskesmas.

appears in the paper.

Keywords : Management Information Systems, Health Services, and Data Integration

\section{PENDAHULUAN}

Inovasi bukan lagi merupakan hal baru dalam sektor publik. Meskipun dalam praktiknya inovasi dalam sektor publik sangat dipengaruhi oleh praktik inovasi yang dilakukan oleh sektor swasta. Keberhasilan inovasi yang dilakukan oleh sektor swasta memberikan motivasi besar kepada sektor publik untuk mengembangkan berbagai jenis inovasi (Taylor, 2018). Oleh karena alasan tersebut maka inovasi dalam sektor publik dianggap sangat penting dilaukan untuk memberikan kontribusi dalam meningkatkan kualitas pelayanan publik terhadap masyarakat. Inovasi dalam sektor publik sangat identik dan sering dikaitkan dengan perubahan atau reformasi yang dilakukan oleh pemerintah yang lebih dikenal sebagai konsep new public management (NPM) (Pollit dan Bouckaert, 2011, Eva dan Torfing, 2012), dan konsep e-government (Safeena dan Abdullah, 2013). Di Indonesia saat ini inovasi dalam sektor publik erat kaitannya dengan adopsi konsep e-government dalam memberikan pelayanan publik kepada masyarakat.

Konsep inovasi dalam sektor publik tersebut mulai dipraktikkan di berbagai negara berkembang karena adanya perkembangan teknologi canggih yang pesat. Konsep inovasi di negara berkembang lebih banyak dikaitkan dengan pengadopsian atau penggunaan teknologi, informasi dan komunikasi (TIK) ke dalam sistem administrasi publik oleh pemerintah (Marieta et al., 2010). Dengan adanya kemajuan teknologi yang dibawa dan dikenalkan dari negara maju, menyebabkan adanya perubahan yang terlihat dari sistem pelayanan yang mulai begeser menjadi lebih modern (Ramseook et al., 2010). Proses inovasi dalam sektor publik di negara berkembang juga melalui penciptaan ide atau gagasan baru, tetapi lebih banyak melalui proses adopsi inovasi yang sudah ada (Tomas dan Jankovic, 2014, Akenroye, 2012, dan Stasishyn dan Ivanov, 2013). Di beberapa negara berkembang, inovasi dianggap sebagai penggunaan teknologi yang canggih ke dalam administrasi publik yang dikenal sebagai konsep $e$ government (Al-Khouri, 2011).

Di Indonesia sendiri penerapan inovasi dalam sektor publik telah dikembangkan pada berbagai sektor, antara lain sektor pendidikan, kesehatan, lingkungan, infrastruktur, dan lain-lain. Inovasi dalam sektor publik di Indosesia telah mengubah karakteristik organisasi publik yang rigid, kaku, dan cenderung status-quo menjadi sistem yang lebih luwes dan dinamis (Suwarno, 2013,
Zakso, 2012 dan Kuipers et al., 2014). Hal yang perlu diperhatikan oleh pemerintah dalam berinovasi seperti halnya inovasi yang dilakukan oleh sektor swasta yaitu penyesuaian dengan budaya organisasi, selain itu juga harus memperhatikan dinamika yang terjadi pada masyarakat (Suwarno, 2013).

Pemahaman inovasi di Indonesia dapat dilihat dari berbagai penerapan inovasi yang dilakukan di semua lini pemerintah. Hampir semua instansi pemerintah, memahami inovasi sebagai adopsi penggunaan TIK kedalam proses administrasi publik yang dikenal dengan konsep e-government. Keterkaitan inovasi dengan $e$ government dapat terlihat dari penerapan TIK pada lingkungan instansi pemerintah dalam menyediakan pelayanan publik secara elektronik (e-government) (Suwarno, 2013, Rokhman, 2011). Meskipun demikian juga terdapat beberapa instansi yang memahami inovasi bukan hanya sekedar penggunaan TIK dalam administrasi publik.

Kondisi pelaksanaan e-government di Indonesia masih sangat bervariasi, meskipun dalam peraturan dijelaskan bahwa pelaksanaannya dapat dilakukan dengan berbagai bentuk kerjasama. Hal ini terlihat dari perhatian pemerintah dalam pengembangan $e$ government masih terpusat pada pemerintah pusat dan pemerintah daerah. Dimana pendefinisian e-goverment oleh pemerintah masih sebatas website. Oleh karena itu pada awal pelaksanaan e-government masih cenderung dimaknai sebagai penyediaan website, meskipun dewasa ini sudah berkembang dengan berbagai aplikasi. Dalam implementasinya terlihat sangat baik pada tahap persiapan (tahap pembuatan) yang artinya hampir setiap instansi pemerintah memiliki website dan proses update informasinya juga berlangsung secara terus menerus. Tetapi berdasarkan data yang ada menunjukkan bahwa terdapat beberapa website pemerintah, baik pusat maupun daerah yang belum dikekola dengan serius. Ketidakseriusan pemerintah dalam mengelola website dapat dilihat dari beberapa website pemerintah yang tidak dapat diakses. Hal ini dapat dilihat dari tabel perkembangan jumlah website pemerintah daerah di Indonesia dibawah ini.

Tabel 1. Perkembangan Jumlah Website Pemerintah Daerah di Indonesia

\begin{tabular}{llll}
\hline & \multicolumn{1}{c}{ Tahun 2008 } & Tahun 2013 \\
\hline $\begin{array}{l}\text { Jumlah } \\
\text { Provinsi }\end{array}$ & Pemerintah & 33 & 33 \\
\hline Jumlah Web Site & 33 & & 33 \\
\hline Bisa dibuka & Data & tidak & 31 \\
\hline
\end{tabular}




\begin{tabular}{llll}
\hline & tersedia & & \\
\hline $\begin{array}{l}\text { Tidak bisa dibuka/offline } \\
\text { /suspended }\end{array}$ & $\begin{array}{l}\text { Data } \\
\text { tersedia }\end{array}$ & tidak & 2 \\
\hline $\begin{array}{l}\text { Jumlah Pemerintah } \\
\text { Kabupaten / Kota }\end{array}$ & 477 & 532 \\
\hline Jumlah Web Site & 390 & & 492 \\
\hline Bisa dibuka & $\begin{array}{l}\text { Data } \\
\text { tersedia }\end{array}$ & tidak & 446 \\
\hline $\begin{array}{l}\text { Tidak bisa dibuka/ offline / } \\
\text { suspended }\end{array}$ & $\begin{array}{l}\text { Data } \\
\text { tersedia }\end{array}$ & tidak & 46 \\
\hline
\end{tabular}

Sumber : Pusdantinkomtel Kemendagri update per Mei 2013

Dari tabel di atas dapat diketahui bahwa jumlah instansi pemerintah daerah baik pemerintah provinsi maupun pemerintah kota/kabupaten yang memiliki dan mengembangkan website mengalami peningkatan yang cukup signifikan. Peningkatan terutama pada level pemerintah kota/kabupaten. Tetapi dari data di atas dapat diketahui bahwa dari total jumlah pemerintah kota/kabupaten yang memiliki website hanya 90,1\% yang dapat dibuka, sedangkan 9,9\% tidak dapat dibuka. Hal ini menunjukkan bahwa banyaknya jumlah pemerintah kota/kabupaten yang memiliki dan mengembangkan $e$ government belum diimbangi dengan kualitas website yang memadai. Meskipun demikian terdapat beberapa pemerintah daerah yang serius dalam melakukan pengembangan e-government.

Hal terpenting dalam inovasi adalah proses difusi inovasi atau penyebarannya. Dimana cepat atau lambatnya suatu inovasi dapat diterima tergantung pada kemampuan suatu inovasi dapat diketahui oleh orang lain. Berbagai upaya dilakukan inovator untuk dapat memperkenalkan suatu inovasi kepada orang lain. Untuk bisa diterima dan diterapkan oleh banyak orang, maka inovator harus dapat mengidentifikasi berbagai kebutuhan yang diperlukan orang lain. Suatu inovasi harus dapat memperlihatkan berbagai kelebihan dan manfaat yang ada dalam inovasi. Seharusnya suatu inovasi memiliki kelebihan dan manfaat yang lebih banyak dibandingkan dengan keadaan dan kondisi sebelumnya. Penerapan suatu inovasi diharapkan dapat memperbaiki kondisi dan kebutuhan orang lain menjadi lebih baik dibandingkan dengan kondisi sebelumnya. Selain itu suatu inovasi untuk dapat diadopsi oleh masyarakat mutlak harus dapat disebarkan dengan mengkominkasikannya kepada masyarakat luas dengan berbagai cara (Rahayuningtyas dan Sofiah, 2013).

Penerapan e-government di Indonesia dimulai sejak tahun 2003 seiring dengan keluarnya Intruksi Presiden Nomor 3 Tahun 2003 tentang Kebijakan dan Strategi Nasional Pengembangan E-government, tetapi kondisi penerapannya bervariasi. Sejak penerapan $e$ government inilah, seluruh instansi yang ada melakukan berbagai inovasi yang dipengaruhi oleh perkembangan TIK yang semakin pesat dan luas. Pemanfaatan TIK dalam sektor publik dapat dilihat diberbagai bidang, seperti bidang pariwisata yang dikenal dengan e-tourism, pendidikan yang dikenal dengan e-education, penganggaran publik yang dikenal dengan e-budgeting, pengadaan barang atau jasa yang dikenal dengan $e$ procurement, kesehatan yang dikenal dengan e-health dan lain sebagainya. Penggunaan TIK dalam administrasi publik diharapkan dapat memberikan pelayanan publik yang cepat, mudah, tepat dan murah, sehingga dapat memberikan keuntungan yang lebih dibandingkan dengan penggunaan cara yang manual atau tradisional.

Penggunaan TIK dalam sektor publik dari tahun ketahun mengalami peningkatan, hal ini dapat dilihat dari peningkatan pemanfaatan layanan berbasis website yang berkembang menjadi aplikasi $e$-government antara lain $e$ planning, e-budgeting, e-project, e-procurement, $e$ delivery, e-controlling, e-service, e-performance dan lain sebagainya. Tetapi peningkatannya hanya terjadi pada kuantitas penggunaan layanan berbasis website bertambah, tetapi kualitasnya belum menjadi perhatian yang lebih. Meskipun demikian banyak penghargaan untuk mengapreasiasi instansi pemerintah yang berhasil menerapkan konsep e-government di lingkungan instansinya. Seperti penghargaan Indonesian Digital Society Award (IDSA) yang dilakukan setiap tahun. Dalam menentukan pemenang dalam penghargaan ini ditentukan melalui empat aspek yaitu initiative, leadership, usership, dan benefit yang dilakukan pada lima pihak yaitu Pemerintah Daerah, Lembaga Pendidikan, Lembaga Pelayanan Kesehatan, UKM Swasta, dan Masyarakat. Dimana tahun 2015 ini hasil penilaian pengharagaan IDSA sebagai berikut.

Tabel 2. Penghargaan Indonesian Digital Society Award (IDSA) Tahun 2015

\begin{tabular}{|c|c|c|c|}
\hline Kategori & Juara 1 & Juara 2 & Juara 3 \\
\hline \multirow[t]{2}{*}{ Best of The Best } & Kota & Kota & \\
\hline & Surabaya & Yogyakarta & \\
\hline \multirow[t]{2}{*}{ e-government } & Kota & Kota & Kota Banda \\
\hline & Surabaya & Yogyakarta & Aceh \\
\hline \multirow[t]{2}{*}{ e-health } & Kota & Kota & Kota Bekasi \\
\hline & Surabaya & Yogyakarta & \\
\hline \multirow[t]{2}{*}{ e-education } & Kota & Kota & Banda \\
\hline & Yogyakarta & Surabaya & Aceh \\
\hline \multirow[t]{2}{*}{ e-tourism } & Kota & Kota Bogor & Kota \\
\hline & Yogyakarta & & Balikpapan \\
\hline
\end{tabular}

Penghargaan tersebut sebagai upaya pemerintah untuk memberikan apresiasi terhadap setiap instansi pemerintah yang telah mengembangkan berbagai macam inovasi di setiap daerah. Selain itu pemberian penghargaan dapat digunakan sebagai motivasi kepada instansi pemerintah untuk mengembangkan berbagai inovasi. Salah satu jenis inovasi yang saat ini mulai dikembangkan oleh pemerintah daerah yaitu Sistem Informasi Kesehatan (SIK) atau yang lebih dikenal dengan e-health. Menurut World Health Organization (WHO) menjelaskan bahwa e-health is the use of information and communication technologies (ICT) in support of health and helath-related field, including health-care service, health surveillance, health literature, and health education, knowledge and research. Penekanan konsep $e$-health yaitu pemanfaatan TIK pada pelayanan kesehatan, dimana dalam perkembangannya masih difokuskan pada pelayanan medis pasien yang hanya dapat diakses pada rumah sakit pusat dan rumah sakit swasta dan oleh pihak tertentu karena untuk mengaksesnya memerlukan biaya yang tidak murah. 
Pemerintah Kota Yogyakarta telah mengembangkan aplikasi yang digunakan untuk sektor kesehatan. Aplikasi yang dikembangkan tersebut yaitu Sistem Informasi Manajemen Puskesmas atau yang lebih dikenal sebagai SIMPUS.

\section{METODE}

Tujuan dalam penelitian ini adalah untuk mengetahui dan mendeskripsikan proses integrasi data melalui implementasi inovasi pelayanan kesehatan di Kota Yogyakarta. Penelitian ini dilakukan pada Pemerintah Kota Yogyakarta dengan unit analisis Dinas Kesehatan dan beberapa Puskesmas di Kota Yogyakarta. Metode yang digunakan dalam penelitian ini adalah deskriptif kualitatif melalui wawancara, observasi, dan dokumentasi. Observasi, wawancara dan dokumentasi dilakukan pada Puskesmas Mantrijeron merupakan puskesmas terbaik se-DIY tahun 2015, Puskesmas Jetis dan Puskesmas Umbulharjo II yang merupakan puskesmas yang dijadikan tempat ujicoba SIMPUS.

\section{HASIL DAN PEMBAHASAN}

\section{SIMPUS sebagai Inovasi Sektor Kesehatan}

Inovasi menurut Rogers (dalam de Vries et al., 2014) mendefinisikan inovasi sebagai suatu ide, gagasan, praktek atau objek/benda yang disadari dan diterima sebagai suatu hal yang baru oleh seseorang atau kelompok untuk diadopsi. Lebih jauh lagi Rogers menjelaskan bahwa suatu yang baru bukan berarti harus sesuatu yang baru sekali, melainkan sesuatu yang sebelumnya sudah ada kemudian dilakukan perbaikan yang menjadi hal yang baru oleh orang lain, maka sesuatu tersebut dapat dikategorikan kedalam sebuah inovasi. Merujuk pada definisi tersebut aplikasi SIMPUS di Kota Yogyakarta dapat disebut sebagai sebuah inovasi dalam pelayanan kesehatan.

Dewasa ini perkembangan konsep $e$-health bukan hanya menfokuskan pada pelayanan medis di Rumah Sakit saja, melainkan pada kegiatan pelaksana pelayanan kesehatan yang dilakukan di Puskemas. Puskesmas merupakan fasilitas pelayanan kesehatan yang menyelenggarakan upaya kesehatan masyarakat dan perseorangan tingkat pertama, dengan lebih mengutamakan upaya promotif dan preventif untuk mencapai derajat kesehatan masyarakat yang setinggitingginya (Peraturan Menteri Kesehatan No 75 Tahun 2014 tentang Pusat Kesehatan Masyarakat (Puskesmas). Untuk menjangkau masyarakat secara keseluruhan maka diperlukan program Sistem Informasi Manajemen Puskesmas atau SIM Puskemas yang terintegrasi dengan baik melalui berbagai kegiatan pelaksana. Dalam program SIM Puskesmas terdapat empat bentuk kegiatan pelaksana antara lain sistem pendaftaran pasien, sistem rekam medis pasien, sistem pengobatan atau farmasi dan sistem pembayaran.

Dalam mempemudah dalam melaksanakan kegiatan pelaksana pelayanan kesehatan di Puskemas, setiap daerah mulai mengembangkan berbagai bentuk strategi atau inovasi. Kegiatan pelaksana pelayanan kesehatan disetiap Puskesmas sebelumnya dilakukan dengan cara manual atau tradisional. Kelemahan dalam penggunaan cara manual atau tradisional menjadi tantangan bagi setiap Puskesmas untuk melakukan pengembangan strategi. Dewasa ini di berbagai daerah mulai mengembangkan berbagai strategi yang memanfaatkan TIK dalam melakukan kegiatan pelaksana pelayanan kesehatan di Puskesmas, salah satunya yaitu Kota Yogyakarta. Dinas Kesehatan Kota Yogyakarta berhasil mengembangkan strategi yang memanfaatkan TIK dalam melakukan kegiatan pelaksana pelayanan kesehatan di Puskesmas yang dikenal dengan aplikasi SIMPUS (Sistem Informasi Manajemen Puskesmas). Aplikasi SIMPUS merupakan salah satu bentuk inovasi dalam sektor publik yang menfokuskan pada bidang kesehatan di Kota Yogyakarta yang dapat mengakomodir semua kegiatan pelaksana pelayanan kesehatan di Puskesmas. Meskipun keberadaan aplikasi SIMPUS melalui berbagai tahap pengembangan.

Kemunculan inovasi dalam sektor publik ini sebagai bentuk komitmen Pemerintah Kota Yogyakarta dalam menerapkan Undang-undang No 23/2014 tentang Pemerintahan Daerah yang termuat dalam pasal 386 tentang Inovasi Daerah. Dalam keseriusannya menerapkan undang-undang ini secara optimal dalam berbagai bentuk inovasi di berbagai sektor, sehingga pada tahun 2015 Pemerintah Kota Yogyakarta dijadikan sebagai Laboratorium Inovasi Daerah oleh Lembaga Administrasi Negara. Perkembangan aplikasi SIMPUS di Kota Yogyakarta dapat dilihat pada tabel dibawah ini.

Tabel 3. Pengembangan Aplikasi SIMPUS di Kota Yogyakarta

\begin{tabular}{|c|c|c|c|}
\hline $\begin{array}{c}\text { Fase } \\
\text { Pengembangan }\end{array}$ & Tahun & Kegiatan Pelayanan & $\begin{array}{c}\text { Leading } \\
\text { Sector }\end{array}$ \\
\hline Manual & $\begin{array}{c}\text { Sebelum } \\
2005\end{array}$ & $\begin{array}{lr}\text { Semua } & \text { kegiatan } \\
\text { pelayanan } & \text { kesehatan } \\
\text { dilakukan } & \text { secara } \\
\text { manual } & \end{array}$ & Puskesmas \\
\hline Transisi & $\begin{array}{c}2005- \\
2011\end{array}$ & $\begin{array}{l}\text { Kegiatan pelayanan } \\
\text { kesehatan sistem } \\
\text { pendaftaran pasies, } \\
\text { pengobatan/farmasi } \\
\text { dan pembayaran } \\
\text { dilakukan secara } \\
\text { manual berbasis } \\
\text { windows dan sistem } \\
\text { rekam medis pasien } \\
\text { menggunakan } \\
\text { aplikasi MedCis }\end{array}$ & Bagian TIT \\
\hline $\begin{array}{l}\text { Aplikasi } \\
\text { SIMPUS }\end{array}$ & $\begin{array}{c}2012- \\
\text { sekarang }\end{array}$ & $\begin{array}{l}\text { Semua kegiatan } \\
\text { pelayanan kesehatan } \\
\text { dilakukan } \\
\text { menggunakan } \\
\text { aplikasi SIMPUS }\end{array}$ & $\begin{array}{l}\text { Seksi } \\
\text { Surveilens } \\
\text { dan SIK } \\
\text { Dinas } \\
\text { Kesehatan }\end{array}$ \\
\hline
\end{tabular}

Sumber : Pedoman Pelaksanaan SIMPUS di Kota Yogyakarta, 2014

Dari tabel di atas dapat diketahui bahwa rekam medis pasien merupakan kegiatan yang harus dilakukan oleh setiap instansi kesehatan baik rumah sakit maupun Puskesmas. Di Kota Yogyakarta, sebelum tahun 2005 kegiatan pelaksana pelayanan kesehatan di Puskesmas dari sistem pendaftaran pasien, sistem rekam medis pasien, sistem pengobatan atau farmasi dan sistem pembayaran dilakukan secara manual atau tradisional. Kemudian pada tahun 2005 Dinas Kesehatan bekerja 
sama dengan bagian Teknologi Informasi dan Telematika (TIT) Kota Yogyakarta mengembangkan aplikasi MedCis yang hanya mengakomodir kegiatan sistem rekam medis pasien. Sedangkan kegiatan pendaftaran pasien, pengobatan atau farmasi dan pembayaran tetap dilakukan dengan cara manual atau tradisional. Pada tahun 2011 Dinas Kesehatan Kota Yogyakarta melakukan pengembangan aplikasi SIMPUS yang dapat mengakomodir semua kegiatan pelaksana pelayanan kesehatan di Puskesmas. Aplikasi SIMPUS dikembangkan untuk memenuhi kebutuhan dan kondisi saat ini yang menyesuaikan dengan perkembangan teknologi. Aplikasi SIMPUS memanfaatkan TIK untuk membantu memudahkan melaksanakan kegiatan pelaksana pelayanan kesehatan di Puskesmas berbasis open source. Oleh karena itu SIMPUS di Kota Yogyakarta dapat diklasifikasikan dalam suatu inovasi. Hal ini didasarkan pada jenis inovasi dibawah ini.

Tabel 4. Jenis Inovasi dalam Sektor Publik

\begin{tabular}{|c|c|c|}
\hline No & Jenis Inovasi & Keterangan \\
\hline \multirow[t]{3}{*}{1.} & Inovasi Proses & $\begin{array}{l}\text { Peningkatan kualitas dan efisiensi pada } \\
\text { proses internal dan eksternal }\end{array}$ \\
\hline & $\begin{array}{l}\text { Proses inovasi } \\
\text { administrasi }\end{array}$ & $\begin{array}{l}\text { Penciptaan bentuk-bentuk organisasi } \\
\text { baru, pengenalan metode baru, } \\
\text { manajemen baru dan teknik baru serta } \\
\text { pekerjaan baru }\end{array}$ \\
\hline & $\begin{array}{l}\text { Proses inovasi } \\
\text { teknologi }\end{array}$ & $\begin{array}{l}\text { Penciptaan atau penggunaan teknologi } \\
\text { baru, diperkenalkan dalam sebuah } \\
\text { organisasi untuk memberikan pelayanan } \\
\text { kepada pengguna dan masyarakat. }\end{array}$ \\
\hline 2. & $\begin{array}{ll}\text { Inovasi } & \text { produk } \\
\text { atau jasa } & \\
\end{array}$ & $\begin{array}{l}\text { Penciptaan produk atau pelayanan public } \\
\text { yang baru }\end{array}$ \\
\hline 3. & $\begin{array}{l}\text { Inovasi } \\
\text { pemerintahan }\end{array}$ & $\begin{array}{l}\text { Pengembangan bentuk-bentuk dan proses } \\
\text { baru untuk mengidentifikasi masalah } \\
\text { social }\end{array}$ \\
\hline 4. & $\begin{array}{l}\text { Inovasi } \\
\text { konspetual }\end{array}$ & $\begin{array}{l}\text { Pengenalan konsep-konspe baru, } \\
\text { kerangka aacuan atau paradigma baru } \\
\text { yang membantu untuk mendesai baru } \\
\text { terhaadap permasalahan dan solusi yang } \\
\text { tepat }\end{array}$ \\
\hline
\end{tabular}

Sumber : de Vries, Hanna et al., 2014

Dari tabel diatas maka SIMPUS di Kota Yogyakarta dapat diklasifikasi dalam jenis inovasi proses yang termasuk dalam proses inovasi administrasi. Dimana pengembangan SIMPUS digunakan untuk mengakomodasi pelayanan kesehatan disetiap puskesmas. Selain itu SIMPUS dikembangkan untuk aktivitas rekam medis pasien. Oleh karena itu SIMPUS di Kota Yogyakarta digunakan khusus untuk internal lembaga, dalam hal ini Dinas Kesehatan dan seluruh Puskesmas di Kota Yogyakarta.

Pengembangan aplikasi SIMPUS berbasis open source ini dikarenakan adanya surat edaran dari Kementerian Riset dan Teknologi dan Kementerian Pemberdayaan Aparatur Negara pada April 2009 tentang upaya percepatan penggunaan perangkat lunak open source di lingkungan pemerintah. Oleh karena itu pada tahun 2012, Dinas Kesehatan Kota Yogyakarta mengembangkan aplikasi SIMPUS berbasis open source yang diterapkan untuk seluruh Puskesmas di Kota Yogyakarta, kemudian pada tahun 2014 mulai dikembangkan di Rumah Sakit Daerah. Pengembangan aplikasi SIMPUS hingga saat ini sudah diterapkan di 18
Puskesmas Pusat, 12 Puskesmas Pembantu, dan 3 Rumah Sakit Daerah. Data instansi tersebut dapat dilihat pada tabel dibawah ini.

Tabel 5. Daftar Instansi Kesehatan yang Menerapkan Aplikasi SIMPUS

\begin{tabular}{|c|c|c|}
\hline Puskesmas Pusat & $\begin{array}{l}\text { Puskesmas } \\
\text { Pembantu }\end{array}$ & $\begin{array}{c}\text { Rumah Sakit } \\
\text { Daerah }\end{array}$ \\
\hline Puskesmas Tegalrejo & Puskesmas Pembantu & Rumah $\quad$ Sakit \\
\hline Puskesmas Danurejan I & Badran & Pemulihan Gizi \\
\hline Puskesmas Danurejan II & Puskesmas Pembantu & Rumah Sakit \\
\hline Puskesmas & Bener & Daerah Kota \\
\hline Gedongtengen & Puskesmas Pembantu & Yogyakarta \\
\hline Puskesmas & Demangan & Rumah Sakit \\
\hline Gondokusuman I & Puskesmas Pembantu & Sehat Lansia \\
\hline Puskesmas & Dukuh & \\
\hline Gondokusuman II & Puskesmas Pembantu & \\
\hline Puskesmas Gondomanan & Joyonegaran & \\
\hline Puskesmas Jetis & Puskesmas Pembantu & \\
\hline Puskesmas Kotagede I & Kepatihan & \\
\hline Puskesmas Kotagede II & Puskesmas Pembantu & \\
\hline Puskesmas Kraton & Mendungan & \\
\hline Puskesmas Mantrijeron & Puskesmas Pembantu & \\
\hline Puskesmas Mergangsan & Nitikan & \\
\hline Puskesmas Ngampilan & Puskesmas Pembantu & \\
\hline Puskesmas Pakualaman & Pakel & \\
\hline Puskesmas Umbulharjo I & Puskesmas Pembantu & \\
\hline Puskesmas Umbulharjo II & Pathuk & \\
\hline \multirow[t]{4}{*}{ Puskesmas Wirobrajan } & Puskesmas Pembantu & \\
\hline & Tegalmulyo & \\
\hline & Puskesmas Pembantu & \\
\hline & Tompeyan & \\
\hline
\end{tabular}

Sumber : Pedoman Pelaksanaan SIMPUS Kota Yogyakarta, 2014

Perkembangan aplikasi SIMPUS berbasis open source di Kota Yogyakarta diharapkan dapat memberikan pelayanan kesehatan yang lebih baik. Penekanan dari aplikasi SIMPUS yaitu pengelolaan rekam medis pasien yang terintegrasi dengan baik. Dalam pelaksanaanya dilakukan monitoring dan evaluasi terhadap yang dilakukan oleh Dinas Kesehatan Kota Yogyakarta yaitu pelaporan SIMPUS setiap bulan, triwulan, semesteran dan tahunan. Dari hasil evaluasi tahun 2013 sampai dengan tahun 2014, pelaksanaan aplikasi SIMPUS di suluruh Puskesmas hingga saat ini sudah dilakukan secara optimal. Bahkan berdasarkan data evaluasi dari Dinas Kesehatan Kota Yogyakarta, dari seluruh Puskesmas yang menerapkan aplikasi SIMPUS terdapat 6 Puskesmas yang berhasil mendapatkan sertifikat ISO 9001. Dimana perolehan sertifikat ISO 9001 menunjukkan kerberhasilan dalam menerapkan aplikasi SIMPUS di setiap Puskesmas. Data Puskesmas tersebut dapat dilihat pada tabel dibawah ini.

Tabel 6. Puskesmas Peraih Sertifikat ISO di Kota Yogyakarta

\begin{tabular}{ll}
\hline No & \multicolumn{1}{c}{ Puskesmas } \\
\hline 1. & Puskesmas Mantrijeron \\
\hline 2. & Puskesmas Umbulharjo II \\
\hline 3. & Puskesmas Jetis \\
\hline 4. & Puskesmas Wirobrajan \\
\hline 5. & Puskesmas Mergangsan \\
\hline 6. & Puskesmas Danurejan II
\end{tabular}

Sumber : Pedoman Pelaksanaan SIMPUS Kota Yogyakarta, 2014 (diolah)

Dari tabel di atas dapat diketahui bahwa sertifikat ISO diberikan kepada 6 Puskesmas yang dapat 
menyediakan pelayanan kesehatan secara prima, cepat dan akuntabel yang salah satunya dipengaruhi oleh penggunaan aplikasi SIMPUS. Aplikasi SIMPUS dapat meningkatkan sistem kerja yang lebih baik dan mendorong penyempurnaan kinerja pelayanan kesehatan pada setiap Puskesmas. Oleh karena itu Dinas Kesehatan Kota Yogyakarta melakukan berbagai upaya untuk mendorong setiap Puskesmas untuk dapat mengoptimalkan penerapan aplikasi SIMPUS, sehingga seluruh Puskesmas yang ada di Kota Yogyakarta dapat memperoleh sertifikat ISO 9001.

\section{Stakeholder dalam Pengembangan SIMPUS}

Stakeholder dalam pengembangan dan implemnetasi SIMPUS di Kota Yogyakarta antara lain : a) bagian Teknologi Informasi dan Telematika (TIT), Dinas Kesehatan, dan Puskesmas di Kota Yogyakarta. Terdapat 18 Puskesmas Pusat dan 12 Puskesmas Pembantu sehingga jumlah keseluruhan Puskemas yang ada di Kota Yogyakarta sebanyak 30 Puskesmas. Stakeholder yang terlibat dalam pengembangan dan implementasi SIMPUS memiliki tupoksi atau tugasnya masing-masing. Stakeholder yang terlibat dalam pengembangan dan implementasi SIMPUS di Kota Yogyakarta dapat dilihat pada gambar dibawah ini.

Gambar 1. Stakeholder dalam Pengembangan dan Implementasi SIMPUS di Kota Yogyakarta

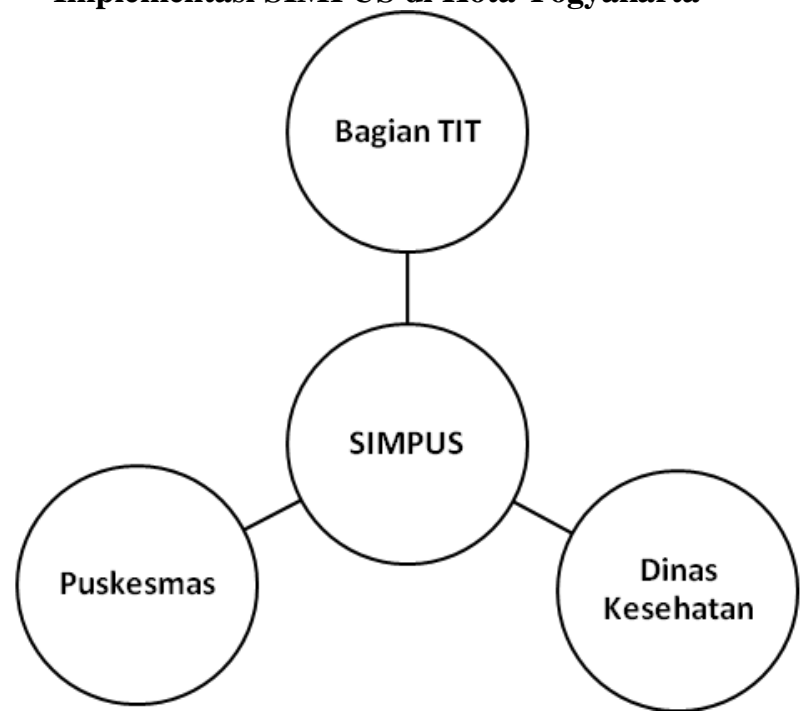

Sumber : Pedoman Pelaksanaan SIMPUS Kota Yogyakarta, 2014

Tupokasi atau peran setiap stakeholder dalam pengembangan dan Implementasi SIMPUS di Kota Yogyakarta sebagai berikut:

- Bagian Teknologi Informasi dan Telematika (TIT) Kota Yogyakarta memiliki peran dalam pengembangan aplikasi SIMPUS yang disesuaikan dengan kebutuhan dari Dinas Kesehatan dan Puskesmas yang ada di Kota Yogyakarta. Bagian TIT membuat aplikasi SIMPUS melalui kordinasi dengan Dinas Kesehatan Kota Yogyakarta. Oleh karena dalam pengembangan aplikasi SIMPUS bagian TIT memiliki peran yang paling penting dalam membuat aplikasi tersebut.

- Dinas Kesehatan memiliki peran sebagai key stakeholder dalam pengembangan dan implementasi SIMPUS di Kota Yogyakarta. Dinas Kesehatan bertugas mengembangkan aplikasi yang sesuai dengan kebutuhan disetiap puskesmas yang ada di Kota Yogyakarta. Dinas Kesehatan juga berperan sebagai implementator aplikasi SIMPUS. Dimana melalui aplikasi SIMPUS Dinas Kesehatan dapat mengakses dimanapun dan kapanpun, sehingga aplikasi SIMPUS memudahkan Dinas Kesehatan dalam melakukan kordinasi dan kontrol kepada pelaksanaan kegiatan/aktivitas pada setiap puskesmas yang ada di Kota Yogyakarta.

- Puskesmas yang ada di Kota Yogyakarta berperan sebagai kelompok sasaran dan pengembangan dan implementasi SIMPUS. Dimana aplikasi SIMPUS dilaksankana di setiap Puskesmas melalui pegawainya.

Apabila merujuk pada jenis Indrajit (2002) yan menjelaskan terdapat tipe layanan dalam konsep $e$ government antara lain iatu : a) government to government $(\mathrm{G} 2 \mathrm{G}), \mathrm{b})$ government to citizens $(\mathrm{G} 2 \mathrm{C}), \mathrm{c})$ government to business $(\mathrm{G} 2 \mathrm{~B})$, dan d) government to employee (G2E). Inovasi aplikasi SIMPUS yang dikembangkan oleh Kota Yogyakarta setidaknya dapat mengakomodir tipe layanan yaitu G2G dan G2C. Tetapi pada pengembangan dan implementasi SIMPUS lebih menekankan pada G2G. Dimana melalui aplikasi SIMPUS ini dapat memangkan hubungan dan proses yang rumit dan membutuhkan waktu yang lama antara Dinas Kesehatan dan seluruh puskesmas yang ada di Kota Yogyakarta.

\section{Integrasi Data melalui Inovasi SIMPUS}

Konsep integrasi data melalui aplikasi SIMPUS dapat terlihat dalam pengambangan dan implementasinya. Dimana Dinas Kesehatan sebagai central data, sedangkan setiap puskesmas yang ada di Kota Yogyakarta sebagai kelompok sasarannya. Pada pelaksanaannya, setidaknya aplikasi SIMPUS di Kota Yogyakarta terdapat beberapa kegunaan antara lain : a) sistem pendaftaran pasien, b) sistem rekam medis, c) sistem pengobatan dan d) sistem billing. Kegunaan aplikasi SIMPUS tersebut dapat dilihat pada gambar dibawah ini. 
Gambar 2. Gambaran Umum Aplikasi SIMPUS di Kota Yogyakarta

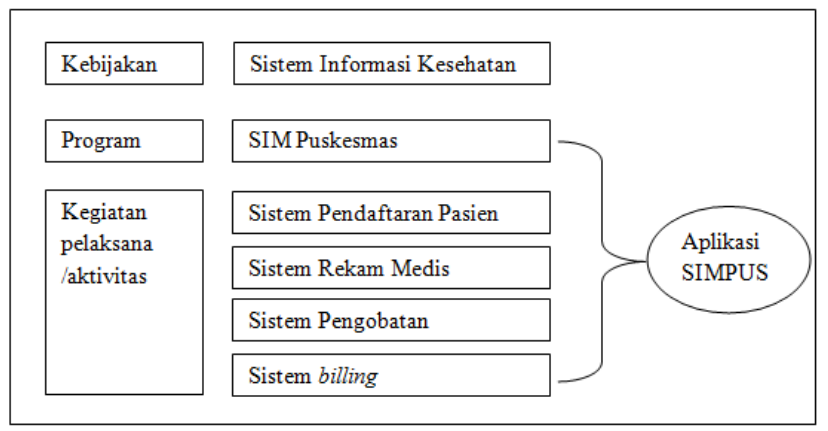

Sumber : Pedoman Pelaksanaan SIMPUS Kota Yogyakartam, 2014

Dari gambar diatas dapat diketahui bahwa setidanya pengembangan aplikasi SIMPUS ditujukan untuk memperbaiki sistem pendaftaran pasien, sistem rekam medis, sistem pengobatan dan sistem billing kepada pasien. Hal ini dikarenakan keempat sistem tersebut saling terkait satu dengan yang lainnya. Meskipun demikian sistem yang paling diutamakan dalam implementasi SIMPUS di Kota Yogyakarta ini yaitu sistem rekam medis.

Selanjutnya seperti penjelasan pada sub bab sebelumnya bahwa setidaknya dalam pelaksanaan SIMPUS di Kota Yogyakarta terdapat dua stakeholder yang paling penting yaitu Dinas Kesehatan dan Puskesmas. Keduanya dapat memanfaatkan dan mengakses SIMPUS sesuai dengan kebutuhannya masing-masing. Puskesmas menggunakan SIMPUS untuk melakukan pelayanan kesehatan kepada masyarakat, sedangkan Dinas Kesehatan menggunakan aplikasi SIMPUS untuk tujuan mengontrol aktivitas setia Puskesmas di Kota Yogyakarta. Hubungan tersebut dapat dilihat pada gambar dibawah ini.

Gambar 3. Hubungan Aplikasi SIMPUS dengan Dinas Kesehatan dan Puskesmas di Kota Yogyakarta

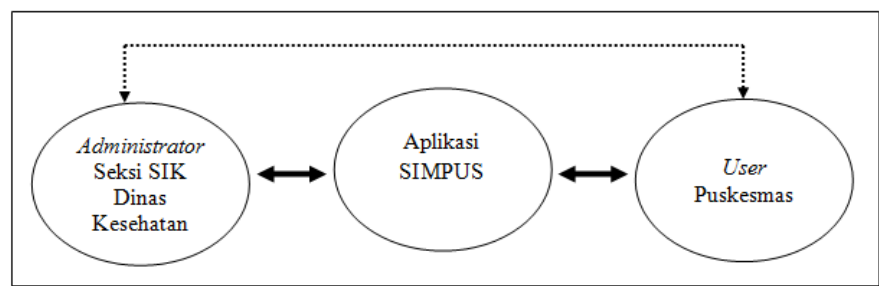

Sumber : Pedoman Pelaksanaan SIMPUS di Kota Yogyakarta, 2014

Hubungan tersebut kemudian dapat merubah alur pelayanan kesehatan di Kota Yogyakarta, terutama dalam hal pelaporan aktivitas setiap puskesmas kepada Dinas Kesehatan. Melalui aplikasi SIMPUS ini setiap puskesmas tidak perlu lagi harus melaporkan aktivitas pelayanan kesehatan yang dilakukan dalam bentuk gardcopy, melainkan Dinas Kesehatan dapat selalu memantau aktivitas setiap puskesmas melalui aplikasi SIMPUS. Dinas Kesehatan dapat mengakses dan memanfaatkan data yang ada di aplikasi SIMPUS kapanpun dan dimanapun dari setiap puskesmas. Integrasi data tersebut dapat dilihat pada gambar dibawah ini.

\section{Gambar 4. Pola Integrasi Data Aplikasi SIMPUS di Kota Yogyakarta}

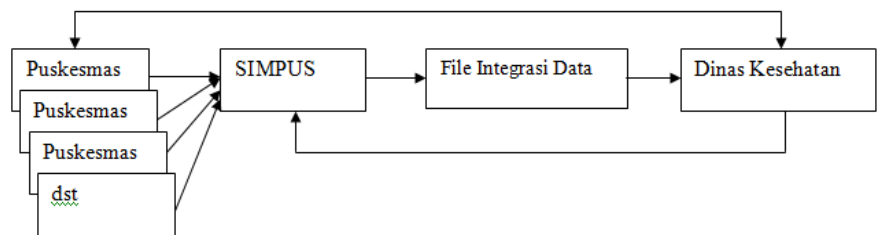

Sumber : Pedoman Pelaksanaan SIMPUS di Kota Yogyakarta, 2014

Dari gambar diatas dapat diketahui bahwa manfaat utama yang dapat dirasakan dalam implementasi SIMPUS di Kota Yogyakarta yaitu terwujudnya integrasi data. Melalui aplikasi SIMPUS Dinas Kesehatan dengan mudah dapat memantau segala ativitas yang dilakukan setiap puskesmas kapanpun dan dimanapun. Hal ini mempermudah alur kordinasi dan pelaporan yang dulunya cenderung ribet dan membutuhkan waktu yang lama. Dengan demikian diharapkan melalui implementasi SIMPUS ini dapat meningkatkan pelayanan kesehatan kepada masyarakat.

\section{PENUTUP}

\section{Simpulan}

Aplikasi SIMPUS di Kota Yogyakarta merupakan sebuat inovasi dalam pelayanan kesehatan kepada masyarakat. Aplikasi SIMPUS dikembangkan oleh Dinas Kesehatan bekerjasama dengan bagian Teknologi Informasi dan Telematika (TIT) Kota Yogyakarta yang diimplementasikan pada seluruh puskemas yang ada di Kota Yogyakarta. Setidanya terdapat 18 Puksemas Utama dan 12 Puskesmas Pembantu, sehingga seluruhnya terdapat 30 Puskesmas yang ada di Kota Yogyakarta yang meneraapkan aplikasi SIMPUS. Perubahan yang dirasakan melalui penerapan aplikasi SIMPUS yaitu adanya integrasi data. Dimana melalui aplikasi SIMPUS aktvitas pelaporan kesehatan setiap puskesmas yang ada di Kota Yogyakarta dapat dilakukan dengan cepat dan mudah. Dinas Kesehatan hanya perlu mengakses aplikasi SIMPUS untuk mendapatkan data kesehatan yang dibutuhkan pada setiap puskesmas. 


\section{Saran}

Dari hasil kajian yang dilakukan setidanya perlu adanya perbaikan dalam pengembangan aplikasi SIMPUS di Kota Yogyakarta yaitu menerapkan aplikasi SIMPUS pada setiap rumah sakit yang ada di Kota Yogyakarta untuk integrasi data rekam medis pasien yang perlu dirujuk ke rumah sakit. Hal ini sangat penting dilakukan agar setiap pasien yang dirujuk ke rumah sakit tida perlu dilakukan aktivitas rekam medis secara lengkap, melalui aplikasi SIMPUS ini setiap rumah sait dapat melihat hasil rekam medis yang dilakukan di setiap puskesmas pada pasien yang dirujuk. Apalagi pasien yang menggunakan pelayanan BPJS. Oleh karena itu perlu adanya implementasi SIMPUS pada rumah sakit supaya Dinas Kesehatan juga dapat melakukan kordinasi dan kontrol kepada setiap rumah sakit yang ada di Kota Yogyakarta. Dengan demikian aplikasi SIMPUS dapat meningkatkan kualitas pelayanan kesehatan di Kota Yogyakarta.

\section{DAFTAR PUSTAKA}

Akenroye. Temidayo O. (2012). Factors Influencing Innovation in Healthcare : A Conceptual Synthesis. The Public Sector Innovation Journal

Al-Khouri, A.M. (2011). An Innovative Approach for EGovernment Tranformation. International Journal of Managing Value and Supplay Chains

Eva, S dan Torfing, J. (2012). Collaborative Innovations in The Public Sector. SAGE Publication

Indrajit, Richardus Eko. 2002. Elektronik Government : Strategi Pembangunan dan Pengembangan Sistem Pelayanan Publik Berbasis Teknologi Digital. Yogyakarta : Andi

Intruksi Presiden Nomor 3 Tahun 2003 tentang Kebijakan dan Strategi Nasional Pengembangan E-government

Kuipers, B.S., Higgs, M.J., Kickert, W.J.M., Tummers, L.G., Grandia, J., dan Van der Voet, J. (2014). The Management of Change in Public Organizations : A Literature Review. International Journal of Public Administration

Marieta, D., Alin, O., dan Pompilu, M. (2010). Efficiency, Effectiveness and Performance of The Public Sector. Romanian Journal of Economic Forecasting

Pollit, C dan Bouckaert, G. (2011). Public Management Reform : A Comparative Analysis. Oxford : Oxford University Press

Rahayuningtyas, E dan Sofiah. (2013). Difusi Adopsi Inovasi Program Sanitasi Total Berbasis Masyarakat. Jurnal Komunikasi UNS

Ramseook, P., Soolakshna, D., dan Perunjodi, N. (2010). Service Quality in the Public Service. International Journal of Management and Marketing Research
Rokhman, A. (2011). E-Government Adopttion in Developing Countriess : The Case of Indonesia. CIS Publication

Safeena, R dan Abdullah, K. (2013). Conceptualization of Electronic Government Adoption. International Journal of Managing Information Technology

Stasishyn, Sofia dan Ivanov, Sergey. (2013). Organization Derobotized : Innovation and Productivity in A Workplace Environment. International Journal of Organization Innovation

Suwarno, Yogi. (2013). Inovasi di Sektor Publik. Laporan Penelitian. STIA-LAN

Taylor, Simon. 20018. Innovation in The Public Sector : Dimensions, Processes, Barriers and Developing a Fostering Framework. International Journal of Research Science

Tomas, M dan Jankovic, D. (2014). Applicability of Diffusion of Innovation Theory in Organic Agriculture. UDC Publication

Undang-undang No 23/2014 tentang Pemerintahan Daerah

Zakso, A. (2012). Inovasi Pendidikan di Indonesia Antara Harapan dan Kenyataan. Jurnal Pendidikan Sosialogi dan Humaniora Vol 1 No 1 April 2010 